\title{
Bancassurance: Tapping into the Banking Strength*
}

\section{Mark Teunissen}

ING Group, Corporate Communications \& Affairs/External Communications, Amstelveenseweg 500, 1081 KL Amsterdam, The Netherlands.

E-mail: mark.teunissen@ing.com

One of the most significant changes in the financial services sector over the past few years has been the appearance and development of bancassurance. Indeed, the distribution of insurance products through banks is gradually becoming widespread in many parts of the world. This article aims to shed more light on this emerging distribution channel. Although bancassurance has not developed at an equal pace throughout the world, it is evident that it provides clear benefits for insurers, banks and customers and is expected to continue to grow. The Geneva Papers (2008) 33, 408-417. doi:10.1057/gpp.2008.22

Keywords: financial services; bancassurance; ING

\section{Introduction}

One of the most significant changes in the financial services sector over the past few years has been the appearance and development of bancassurance. Indeed, the distribution of insurance products ${ }^{1}$ through banks is gradually becoming widespread in many parts of the world. This article aims to shed more light on this emerging distribution channel. Although bancassurance has not developed at an equal pace throughout the world, it is evident that it provides clear benefits for insurers, banks and customers and is expected to continue to grow. In the following section the concept of bancassurance, and the various models through which it operates, will be explained. In the next section, the growth of bancassurance throughout the world is discussed, after which the subsequent section will elaborate on the main drivers behind this growth. In the penultimate section, ING's experiences with bancassurance, particularly in two important growth regions - Central Europe and Asia/Pacific will be highlighted after which the last section will conclude by sketching the (positive) outlook for bancassurance.

\section{The concept of bancassurance}

Bancassurance can be generally defined as the joint effort of banks and insurers to provide insurance products and services to the bank's customer base. ${ }^{2}$ Under this

\footnotetext{
* The views in this article do not necessarily represent the views of ING Group.

${ }^{1}$ Although non-life bancassurance is developing in a number of countries, the focus of this article is on the provision of life insurance products and services through banks.

${ }^{2}$ Swiss Re (2007).
} 
broad definition, a number of very diverse forms of bancassurance models are being practiced across the world. The choice of the specific bancassurance model depends on numerous factors, including the social-economic, cultural and regulatory environment of the market, the market infrastructure, as well as customer preferences. Also, although generally a certain model is predominant in a country, there is no country where bancassurance relies on a single business model. Having said this, a general classification of bancassurance models can be made on the basis of the legal ownership structure, or in other words the level of integration between the insurer and the bank. On this basis, the main bancassurance models are the pure distributor model, the strategic alliance model, the joint venture model and the financial holding company model. ${ }^{3}$

\section{Pure distributor}

In this model, the bank acts as an intermediary offering products of more than one insurance company. The insurance company usually pays distribution commissions to the bank, which are in turn offset by entry and management fees charged to policyholders. The relationship between the bank and the insurer may also be complemented by a more or less significant shareholding or cross-shareholding. The business logic for such a model is the recognition by the bank of a real need to be in a position to offer insurance products to its customers while being unable or unwilling to develop such expertise internally, also because this would entail significant upfront investments. It is generally perceived that this model works well in markets where customers value advisor independence. ${ }^{4}$ At the same time, a potential disadvantage for insurers is that they have little control over which customers the products are being sold to.

\section{Strategic alliance}

In case of a strategic alliance between a bank and an insurer, the banks sell the product of only this particular insurance company. A main advantage for the bank is that it is able to select the best insurance provider in terms of, for instance, quality of products offered and brand image. At the same time, the insurance company gains access to the bank's customer base without having to make a major financial investment. A potential disadvantage is that low levels of integration between the bank and the insurer remain, as both companies continue to operate as separate entities.

\section{Joint venture}

In this business model, the bank and the insurer establish a jointly owned insurance company or distributor (through more or less balanced shareholdings), as such creating a new entity. The joint venture distributes its products only through the

\footnotetext{
${ }^{3}$ LIMRA International (2007).

${ }^{4}$ Fitch Ratings (2006).
} 
network of its banking parent. In addition, the relationship between the bank and the insurer is sometimes reinforced by a strategic shareholding. An advantage of this model is that there are equal partnerships and joint decision-making and that partners can leverage each other's strengths as each one will be focusing on its line of business.

\section{Financial holding company}

In this business model, a holding company owns both an insurer and a bank - often referred to as a financial conglomerate. Potential advantages of this model are that operations and systems can be fully integrated; there is high capability to leverage on the bank's existing customers; there is the possibility of one-stop shopping for financial services for customers; and, finally, there is the potential for developing fully integrated products. At the same time, the fact that conglomerates visibly run both banking and insurance activities with typically a common brand name does not necessarily mean that there is much interaction and integration between the two.

The above classification on the basis of legal criteria of course gives a generalisation of reality. In practice, a wide range of hybrid bancassurance models exists and other classifications can easily be made, for instance on the basis of the sources of income of banks participating in bancassurance. Next to the usual commission income, profit sharing agreements between the insurance company and the bank are common in bancassurance. Following this classification, a 100 percent profit share for the bank would imply that it owns the specific insurance company, while a 0 percent profit share de facto implies that the bank only acts as a pure distributor.

In general, the most prevalent bancassurance model - in terms of legal ownership - throughout the U.S., Asia and Latin America is the pure distributor model, while models in Europe tend to be more integrated, with strategic alliances and joint ventures being common. The types of insurance products sold through banks also vary throughout the regions of the world. ${ }^{5}$ In Asia, the main products tend to be savingsoriented, such as endowments and investment-linked products. These are basically deposit replacement products and are popular because they earn a higher interest rate than bank deposits. In Latin America, pension products and individual life products are very popular. In southern Europe, bancassurance products are mainly medium and long-term tax-advantaged investment products, while in other parts of Europe single premium unit-linked products are popular, as is term insurance because it is often tied to mortgages. In the U.S., investment products, in particular fixed annuities, are the main life insurance products sold through banks.

\section{Developments in bancassurance around the world}

Over the last decade, bancassurance has become an important distribution channel in many insurance markets around the world. Its prevalence is most pronounced in (southern) Europe, but its use has also spread to other regions, in particular emerging

\footnotetext{
${ }^{5}$ LIMRA (2007).
} 
Table 1 Share of bancassurance distribution in selected markets $(\%, 2006)$

\begin{tabular}{|c|c|c|c|c|}
\hline (Life insurance) & Bancassurers & Agents & Brokers & $\begin{array}{l}\text { Others } \\
\text { (incl. direct sales) }\end{array}$ \\
\hline \multicolumn{5}{|l|}{ Americas } \\
\hline US & 2.0 & NA & NA & NA \\
\hline Canada & 1.0 & 60.0 & 34.0 & 5.0 \\
\hline Brazil & 55.0 & NA & 30.0 & NA \\
\hline Mexico & 10.0 & 90.0 & & \\
\hline Chile & 13.0 & 87.0 & & \\
\hline \multicolumn{5}{|l|}{ Europe } \\
\hline UK & 20.3 & 10.0 & 65.0 & 5.0 \\
\hline France & 64.0 & 7.0 & 12.0 & 17.0 \\
\hline Germany & 24.8 & 27.1 & 39.4 & 8.7 \\
\hline Italy & 59.0 & 19.9 & 9.4 & 11.7 \\
\hline Spain & 71.8 & 15.4 & 5.4 & 7.4 \\
\hline Belgium & 48.0 & 3.2 & 26.5 & 22.3 \\
\hline Portugal & 88.3 & 6.9 & 1.3 & 3.5 \\
\hline Poland & 14.4 & 39.7 & 4.3 & 41.6 \\
\hline Turkey & 23.0 & 30.1 & 0.8 & 46.2 \\
\hline \multicolumn{5}{|l|}{ Asia } \\
\hline South Korea & 8.5 & 91.5 & & \\
\hline China & 16.3 & 83.7 & & \\
\hline Taiwan & 33.0 & 11.7 & 6.6 & 48.7 \\
\hline Malaysia & 45.3 & 49.4 & 2.4 & 2.9 \\
\hline Australia & 43.0 & 57.0 & & \\
\hline
\end{tabular}

Source: Swiss Re. For the Netherlands, in 2005, the share of bancassurance distribution was 13 percent (source: McKinsey). As mentioned by Swiss Re and others, data on bancassurance are not always reliable and should therefore be treated as indicative.

markets. ${ }^{6}$ At the same time, due to country-specific circumstances, bancassurance has not developed at an equal pace throughout the world and regional disparities persist (see Table 1).

Overall, Europe has the highest bancassurance penetration rate, with life bancassurance accounting for more than half of premium income in many markets. At the same time, while banks represent the dominant distribution channel in southern Europe (France, Italy, Spain and Portugal) and Belgium, they are far less important for the distribution of life insurance products in countries like the Netherlands, Germany and the U.K. A number of reasons could explain this. First, banking markets are different across Europe. In the U.K., for instance, there is relatively low bank density, with commensurately fewer opportunities to sell life insurance products, while other countries such as Spain are characterised by very high bank density. Second, life insurance markets are more mature in northern Europe, which makes it harder for banks to capture insurance business in these countries. Also, in countries like Italy, France and Spain, a high degree of regulatory freedom and positive tax

\footnotetext{
${ }^{6}$ Swiss Re (2007).
} 
treatment favoured the development of bancassurance products in the 1990s, although these tax advantages have been gradually withdrawn since then.

In Central and Eastern Europe, bancassurance accounts for 14-22 percent of life premiums. ${ }^{7}$ An important driver has been the increasing penetration of foreign banks and insurers in the region, also driven by EU accession of some Eastern European countries, transferring best practices and experiences from Western Europe. Also, the expansion of bank credits (mortgages, consumer credits), combined with tightened risk management, has increased the demand for loan protection by banks, fostering the distribution of life insurance products.

In North America, bancassurance is not widely used. In the U.S., regulatory barriers have been a major hurdle, although bancassurance has been allowed since 1999 with the signing of the Gramm-Leach-Bliley Act in 1999. Also, one of the major reasons cited for the low interest of banks in bancassurance is the perceived low profit margin on insurance products versus banking products. Finally, customers in the U.S. are used to purchasing insurance from agents and many are even unaware that insurance is sold by banks. Consequently, only 2 percent of individual life insurance sales in the U.S. are currently channelled through banks (see Table 1).

In Latin America, bancassurance has grown steadily due to improved macroeconomic and favourable tax conditions, financial liberalisation and because foreign insurance companies have replicated their successful experiences from other markets in the region. In Asia, bancassurance is developing fast. Although it was virtually nonexistent in 2000, bancassurance accounted for approximately 28 percent of life insurance (and 2 percent of non-life) distribution in $2005 .{ }^{8}$ Main contributing factors to this rapid increase are insurers' desire to diversify away from costly agency distribution, a deregulation process that is taking place, and the strong interest from banks to broaden their income base.

\section{Drivers of bancassurance}

In general, and based on the experiences in the different regions around the world as discussed in the previous section, a number of factors drive the development of bancassurance. ${ }^{9}$ First of all, a supportive regulatory regime is critically important. Liberal regulations on ownership of insurance companies by banks and on the sale of insurance products through banking networks are clearly a precondition for bancassurance to develop. Indeed, regulators around the world have been quite favourable to promoting the development of bancassurance in recent years, as it promotes the competition among insurance companies and increases insurance ownership among consumers. Second, through bancassurance, insurers have access to the bank's client base, which may be a new source of business for them. Also, bancassurance can be a relatively easy way for foreign insurance companies to enter a new market, as linking up with a domestic bank allows the insurer a quick entry into

\footnotetext{
${ }^{7}$ Ibid.

${ }^{8}$ Ibid.

${ }^{9}$ Swiss Re (2007); LIMRA International (2007).
} 
the market and allows it to leverage the bank's strength in the local market. Third, for banks, bancassurance is an additional source of revenue. As in many countries the banking market is highly competitive, banks can increase income through bancassurance, such as via commissions and profit-sharing agreements. Also, they can spread their fixed costs over the life insurance business as well and have an opportunity to increase the productivity of staff, as they now have the opportunity to expand their client offering with insurance products. Fourth, a positive fiscal treatment of long-term savings products in a number of countries has favoured the development of bancassurance, as bancassurers were able to exploit these tax advantages by offering simple, low cost, long-term savings products, which were an attractive alternative to the traditional, more complex offering of the insurance sector.

Fifth, banks' insurance sales are high in countries where the products tend to be relatively simple and standardised, while bancassurers generally have had limited success where expert advice is required to sell complex products. An example of the latter is pensions. In mature pension markets, such as the Netherlands, Switzerland and the U.K., where individuals and employers can influence the way pension investments are managed, more complex financial products have been developed, in turn creating an important role for non-bank brokers. However, when pensions are in large part managed by the state, the public's appetite for independent financial advice is more limited, and the opportunities for banks are commensurately better. Sixth, and linked to the previous factor, an important determinant for the success of bancassurance is the relative strength of alternative distribution channels. In some countries, like the Netherlands and the U.K., strict regulatory requirements and product complexity have been conducive to the growth of a strong independent broker sector, with adverse effects on bancassurance. Last but certainly not least, a critical success factor is the degree to which the bank and the insurer are operationally integrated. The more key operational processes such as product development, sales, IT and remuneration are integrated, the more successful bancassurance will be.

\section{Bancassurance: the case of ING}

One of ING's core business capabilities is its extensive distribution reach, including a broad presence in developing markets (see box for more information on ING). Seventy-five million customers are served through different distribution channels: ING's own online and banking channels, through tied agents and via distribution agreements with other parties. Within this multichannel approach, bank distribution increasingly is a key distribution channel for ING. Indeed, ING has a retail banking footprint in the nine largest economies of the world and in 75 percent of the top 20 countries. Given the global scale on which ING is operating, it takes a pragmatic approach to bank distribution by using a wide range of bank distribution models, always taking into account the sophistication and characteristics of the specific life insurance market in which it operates. In a number of markets, ING distributes life insurance products through its own banking channels, leveraging on the fact that ING operates both banking and insurance activities. This is the case in countries with 
mature insurance markets like the Netherlands, where insurance products of Nationale-Nederlanden are being sold through ING's banking channels, ING Bank and Postbank, ${ }^{10}$ and Belgium where ING's insurance products are being sold through ING's banking labels, ING Bank and Record Bank. However, own banking channels are also used in countries such as Poland, through ING Banks Slaski and in India, through ING Vysya Bank. At the same time, in many countries ING has concluded distribution agreements (e.g. in Japan, China, South Korea, Malaysia and Central Europe), established joint ventures (e.g. in Australia, New Zealand, South Korea and India) and purchased strategic stakes in banks (e.g. in India, China and Thailand). Given this wide spread of ING's bancassurance activities around the world, we will focus here on ING's experiences in two important growth regions, Central Europe and Asia/Pacific, where bancassurance is quickly establishing itself as an important force in insurance, as indicated in the above section on developments in bancassurance around the world.

\section{ING at a glance}

ING is a global financial services company providing banking, investments, life insurance and retirement services. It serves more than 75 million customers in Europe, the United States, Canada, Latin America, Asia and Australia. Through this global scale, its experience, expertise and customer service, ING wants to meet the needs of a broad customer base, comprising individuals, families, small businesses, large corporations, institutions and governments. Based on market capitalisation (31 December 2007), ING is one of the largest financial institutions worldwide.

Central Europe is a fast-growing financial services market. ING was one of the first foreign financial services companies there when the markets opened up in the early nineties. It has since grown to be the number one pension and life insurance provider in the region and has a substantial banking presence in many countries. In line with ING's multichannel distribution approach around the globe, in Central Europe, ING adapts its distribution model (tied agents, brokers, direct (internet), bank distribution) to suit the unique characteristics of the country and the local product mix of ING. Tied agents still remain the largest distribution channel in the region for life insurance and pensions and are extremely effective in a Greenfield start-up. At the same time, brokers have emerged as a powerful distribution channel of insurance products in many areas, while as a result of the increased penetration of the internet, direct distribution of simple products is increasing.

Nevertheless, it is evident that retail banks are increasingly becoming important platforms for different products, including investments, life insurance and retirement services. Leveraging on this trend, ING has proprietary retail banking platforms in three large countries with significant growth potential, Poland, Romania and Turkey and is preparing the launch of a fourth one, in Ukraine, where the first branches are to open soon. In other countries, ING is entering third-party distribution agreements

\footnotetext{
${ }^{10}$ In the first quarter of 2009 these two banking operations will be combined and will be rebranded ING.
} 
with local banks. A successful example of the latter is the distribution partnership between ING and Piraeus Bank in Greece. ${ }^{11}$ ING recently concluded a 10-year distribution partnership with Piraeus Bank following 5 years of cooperation as a joint venture. Within this partnership, ING is manufacturer of the ING Piraeus insurance production, with Piraeus Bank as the distributor. The cooperation has proved to be successful, with a rise in market share of the joint venture ING Piraeus from 1.1 percent in 2004 to 3.7 percent in 2007 and from the 14th to the 8th position in the life market in Greece.

ING has been a very active player in the development of bancassurance in Asia/ Pacific. It all began 6 years ago in Australia and New Zealand, when ING entered a funds management and life insurance joint venture with one of Australia's largest banks, ANZ. In the meantime, other relationships have included a joint venture with Kookmin Bank in South Korea in 2004 and bank distribution agreements with the Bank of Beijing and 33 banks in Japan. In 2007, a distribution agreement was concluded with the China Construction Bank (CCB), in which ING's life and investment-linked products are sold through CCB's branches across Hong Kong and Macau. Including the most recent agreement, a 10-year alliance with Malaysia's Public Bank Berhad, the country's second largest bank, ING has negotiated more than 200 bank distribution agreements with banks in the Asia/Pacific region. These bank agreements mean that ING products and services are marketed through more than 16,000 branches in the region. But as indicated earlier, ING does not only focus on bank distribution agreements. In November last year, for instance, ING purchased a 30 percent stake in the Thai retail bank TMB. Apart from assisting the bank to develop its business, this stake will enable ING to distribute life insurance products through the bank's branches, and the plan is to later distribute general financial services products. Likewise, ING owns a majority stake in ING Vysya Bank in India and also has a strategic investment in Bank of Beijing, China. These investments provide preferred distribution access for ING's life insurance products through the branch network of these banks.

This focus on bank distribution has substantially lifted ING's reach in this rapidly growing region. ING is now a market leader in bancassurance sales in Asia/Pacific (as well as the second largest insurer and asset manager). In 2007, sales from bancassurance operations contributed to 28.3 percent of the premium income of ING's overall insurance sales in Asia/Pacific. And from 2003 to 2007, growth of the bank distribution business has surged 61 percent on a compound annual growth rate basis.

A number of factors can help explain these positive developments. First and most importantly, ING clearly benefits from its considerable global experience in both banking and insurance. When ING engages into discussions with banks, ING is seen as both a life insurance company and a bank, which in itself creates a competitive advantage over other - stand-alone - insurance companies, as ING fully understands the bank business. At the same time, the success in bancassurance hinges on understanding and respecting a bank's business proposition and culture, and on not trying to unduly alter either. It is crucial that in all relationships and joint ventures,

${ }^{11}$ Within ING's reporting structure, Greece is part of the business unit "Central and Rest of Europe." 
both parties need to understand their respective positions. It is natural that banks generally take the lead as they are responsible for distribution. Insurance companies, on the other hand, should always be in the leading position on the product development side, in order to make sure that the insurance product does not become a commodity. In this respect, ING's experiences make clear that it is crucial that the insurance company builds a tailored solution for the bank, taking into account organisation, operations, marketing and IT, and then build the relationship with the bank around this.

\section{Future outlook}

Given the strong development of bancassurance around the world, it is useful to assess what the future will entail. In general, the outlook for bancassurance remains positive, as a number of trends point to further growth of this distribution channel. First of all, customer preferences are changing and reshaping the financial industry. As more customers live longer they know they need to increasingly save enough to enjoy retirement. And across the globe, especially in emerging markets, people are becoming wealthier. As customers accumulate more wealth, this drives strong growth in total client balances. In particular, there is a growing demand for savings and investment products, irrespective of whether these products are provided by a bank or an insurer. And with many products and services to choose from, customers expect strong investment performance from their financial services providers. Against this backdrop, the life insurance sector is going through a paradigm shift from traditional to investment-linked investment products. And because of this shift, distribution is moving increasingly into the domain of banking (see Figure 1).

Second, banks have a significant competitive advantage over other distribution channels. Banks can fulfil many customer needs, covering the full range of products from liquidity to lending and investing. Moreover, compared to insurance companies, banks benefit from the visibility and convenience of their branch network, the trust

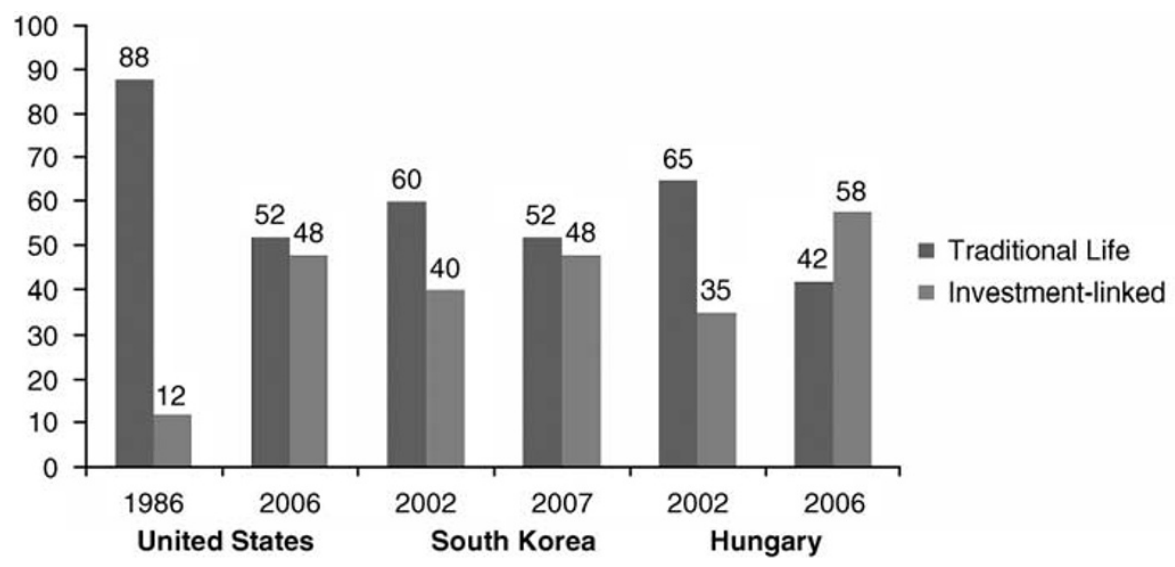

Figure 1. Shift to investment-linked products (share of life premium by product group). Source: McKinsey 
that most clients have in their bank and its brand as well as the more frequent interaction with the client than in case of traditional life insurance channels. As such, banks are structurally well positioned as they offer opportunities for early customer acquisition and maintaining customer relationships. Finally, these factors particularly hold true in emerging markets, which together with the continuing liberalisation, deregulation and inflow of foreign insurance companies will likely contribute to a strong growth of bancassurance in these markets. ${ }^{12}$

\section{References}

Fitch Ratings (2006) Bancassurance or not bancassurance?, Financial Institutions Special Report (February), New York.

LIMRA International (2007) Bancassurance Around the World, Windsor, CT: LIMRA International.

Swiss Re (2007) 'Bancassurance: Emerging trends, opportunities and challenges', Sigma 5: 1-39.

\section{About the Author}

Mark Teunissen works as Senior Communication Advisor in the Corporate Communications and Affairs Department of ING Group. Previously he worked as Senior Economist in the Monetary and Economic Policy and Supervisory Strategy Departments at the Dutch Central Bank.

\footnotetext{
12 Swiss Re (2007).
} 